\title{
Features of reclamation of oil-contaminated lands in the conditions of the Middle $\mathrm{Ob}$
}

\author{
Nina Rogova ${ }^{1, *}$ \\ ${ }^{1}$ Moscow State University of Civil Engineering, 26, Yaroslavskoe shosse, 129337, Moscow, Russia
}

\begin{abstract}
In the process of extraction, collection, transportation and primary processing of hydrocarbons, the lands of the fields are often damaged. For the further operation of the oil field, it is necessary to carry out not only reclamation of disturbed lands, but also oil-contaminated lands formed as a result of accidental spills. The natural environment of Western Siberia is a fragile environment and interference in its existing balance as a result of accidental spills of oil products and pollution of land and water bodies leads to negative consequences for the flora and fauna. If the impact on the natural environment during the development of oil and gas fields during the placement of oil field facilities can still be considered as permissible, then the ingress of oil products into the environment should be considered as negative with far-reaching consequences.
\end{abstract}

\section{Introduction}

Land reclamation should be carried out in accordance with the Russian State Standard GOST R 57447-2017 "Reclamation of lands and land plots contaminated with oil and oil products" [1] in two main stages: technical and biological. Depending on the scale of pollution (area), time of year, weather and climatic characteristics of the region, as well as the transport accessibility of the site and the availability of technical means, reclamation can be carried out both in one season and over several years.

As of 01.01.2020, 10,429 areas contaminated with oil and oil products with a total area of 2,220.85 hectares were entered into the register of the Federal Service for Supervision of Natural Resource Usage of Yugra [3].

\footnotetext{
*Corresponding author: doptaganka@yandex.ru
} 


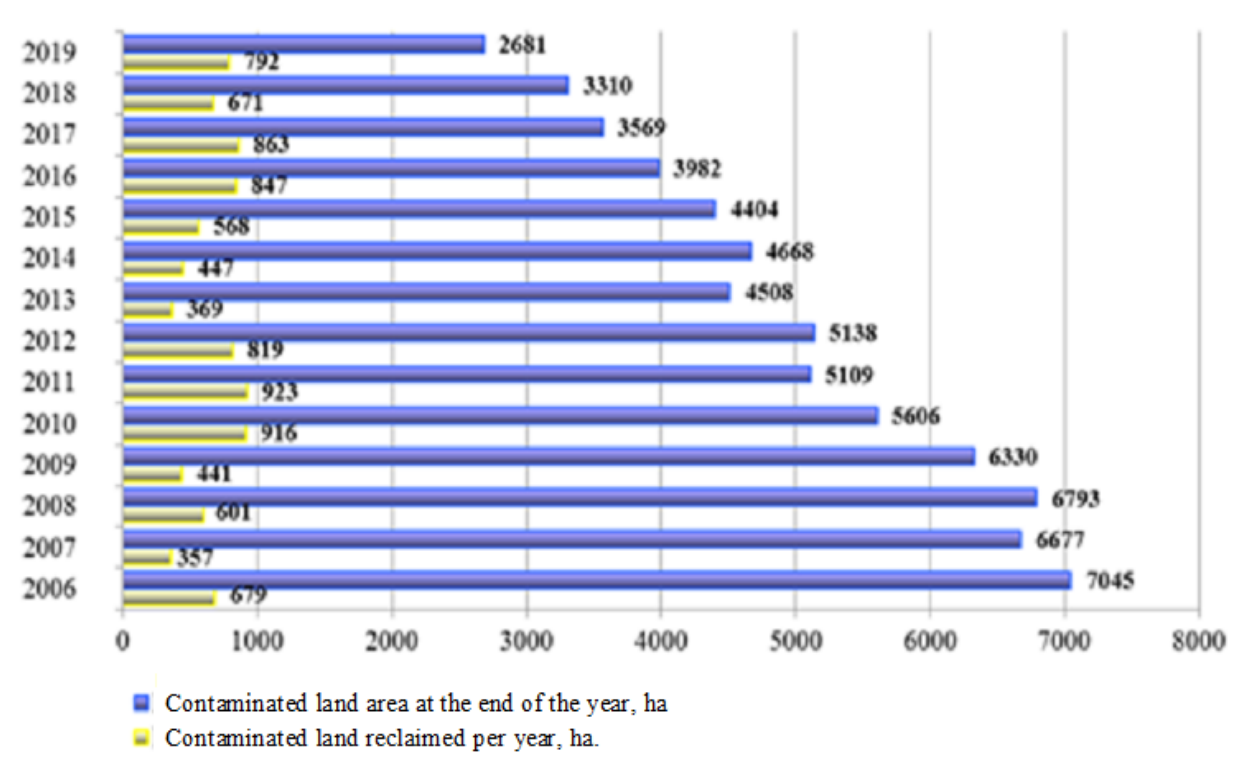

Fig. 1. Dynamics of the formation of lands contaminated with oil products and the volume of reclamation carried out in the territory of the Khanty-Mansi Autonomous Okrug - Yugra.

The dynamics of the formation of oil-contaminated and reclaimed lands on the territory of the Khanty-Mansi Autonomous Okrug - Yugra, shown in the graph in figure 1, indicates an improvement in the general picture, but not enough to avoid its discussion.

\section{Materials and methods}

Reclamation of an oil-contaminated site provides for two main stages: technical and biological, while for the optimal organization of work, preparatory stage is designated in the technical one and final - in the biological one.

The technical stage of reclamation of an oil-contaminated area primarily provides for the elimination of an emergency situation and limiting the spread of an oil spill beyond its borders, after which work is carried out to collect surface oil, as well as to organize the relief and landscape of the contaminated area (including cutting down vegetation), allowing the most promptly carry out work on the remediation of the contaminated site. Localization of areas located on dry lands is carried out by an earth bunding, in wetlands with a developed network of surface water bodies and watercourses, barriers, dams, water locks, enclosing canals or booms are performed.

The biological stage of reclamation of oil-contaminated lands includes measures to restore their economic and environmental value, the introduction of organic and mineral fertilizers, biopreparations of oil-oxidizing action, sowing herbs and planting woody plants. The activities carried out at the biological stage are aimed at improving conditions for the subsequent restoration of soil, species diversity of flora and fauna. The choice of methods for biological reclamation of oil-contaminated lands is determined taking into account the peculiarities of natural and climatic conditions, biodiversity, the achieved parameters of cleansing soils from oil at the previous technical stage, economic and environmental feasibility, intended use and permitted use. At the final stage of biological reclamation, the formation of a vegetation cover is carried out by sowing seeds of perennial grasses, which will provide additional cleaning of the land and prepare it for replacement by natural species of grasses and woody plants. 


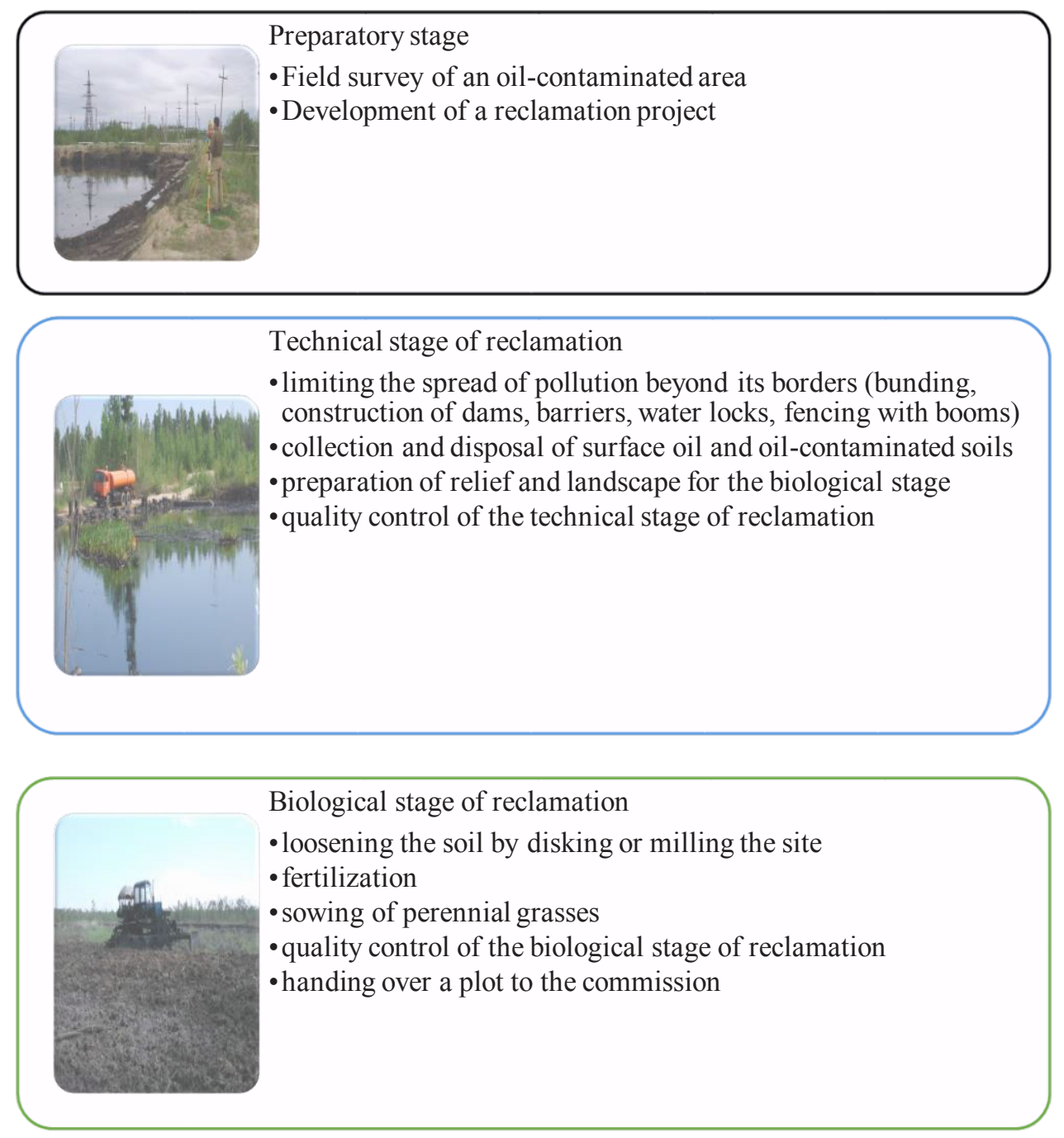

Fig. 2. Block diagram of the main stages of reclamation of oil-contaminated lands.

After the emergency situation is eliminated, the oil producing company must start reclamation of the oil-contaminated area. To carry out reclamation work at a certain site, the enterprise needs to develop a work production project (WPP) for the reclamation of the oil-contaminated site [6], which is being developed in order to identify the necessary types of work and their volumes at the technical and biological stages, as well as the correct organization of work. This document is mandatory for reclamation after elimination of an emergency at oilfield equipment. Otherwise, the reclamation process will be illegal. Figure 2 shows a general block diagram of the formation and liquidation of an oil-contaminated area.

From this stage, the organizational problems of the enterprise begin, leading to the ineffectiveness of the reclamation of oil-contaminated lands.

Accidents at oilfield equipment that led to contamination of land or water bodies that occurred in the winter, at best case, can only be localized by erecting an earthen dam along the perimeter of the site and partially collecting the oil spill. It is possible to fully survey the site and develop a WPP only after the snow cover has melted. After the development of the 
project, it must be approved by the enterprise and then sent for approval to the interested government agencies. All this takes time, and the summer period during which reclamation is allowed in Western Siberia is short and is about 4-5 months.

In practice, for the prompt implementation of reclamation works, enterprises cover themselves with a "standard project of work production" [5], which cannot be a reliable document, since it is developed for "all cases of pollution" and does not take into account all the features of a particular contaminated site: first of all, the nature of pollution, its distribution by relief and water, the degree of penetration into the ground, and much more. Figure 3 shows an example of pollution of a raised bog and the ingress of oil into a stream. Figure 4 is an example of dry land pollution, and Figure 5 - roadside ditch contamination.

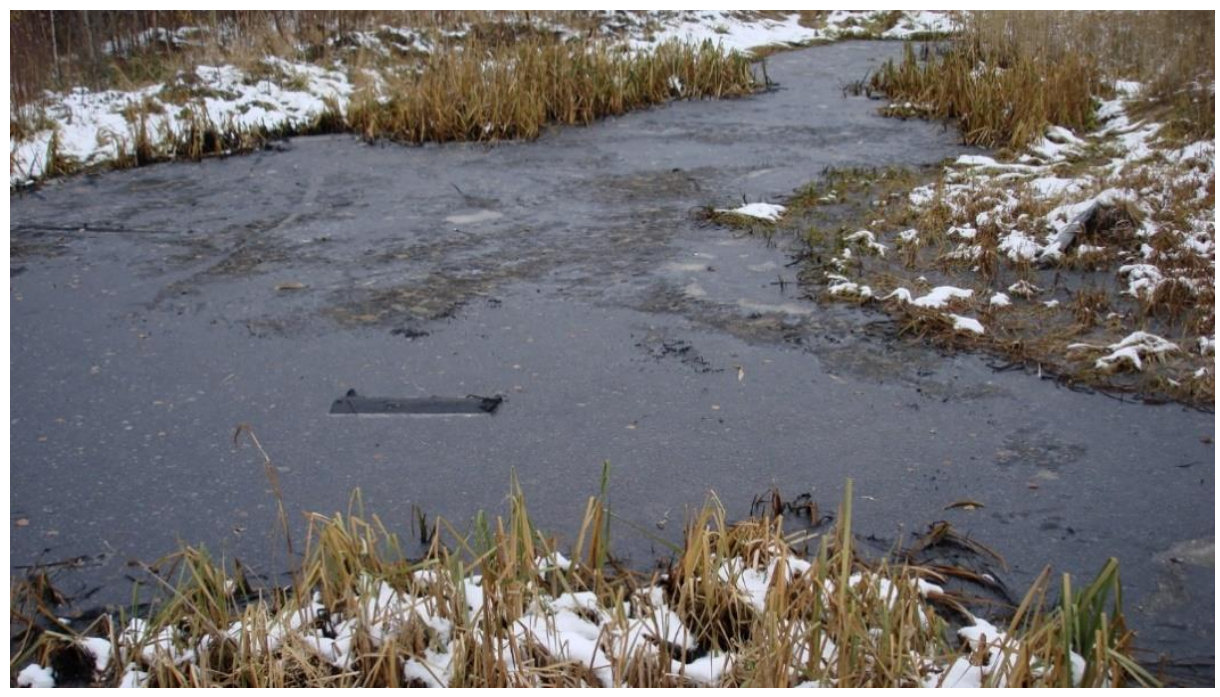

Fig. 3. Pollution of the raised bog and the ingress of oil into the stream (photo from the author's archive).

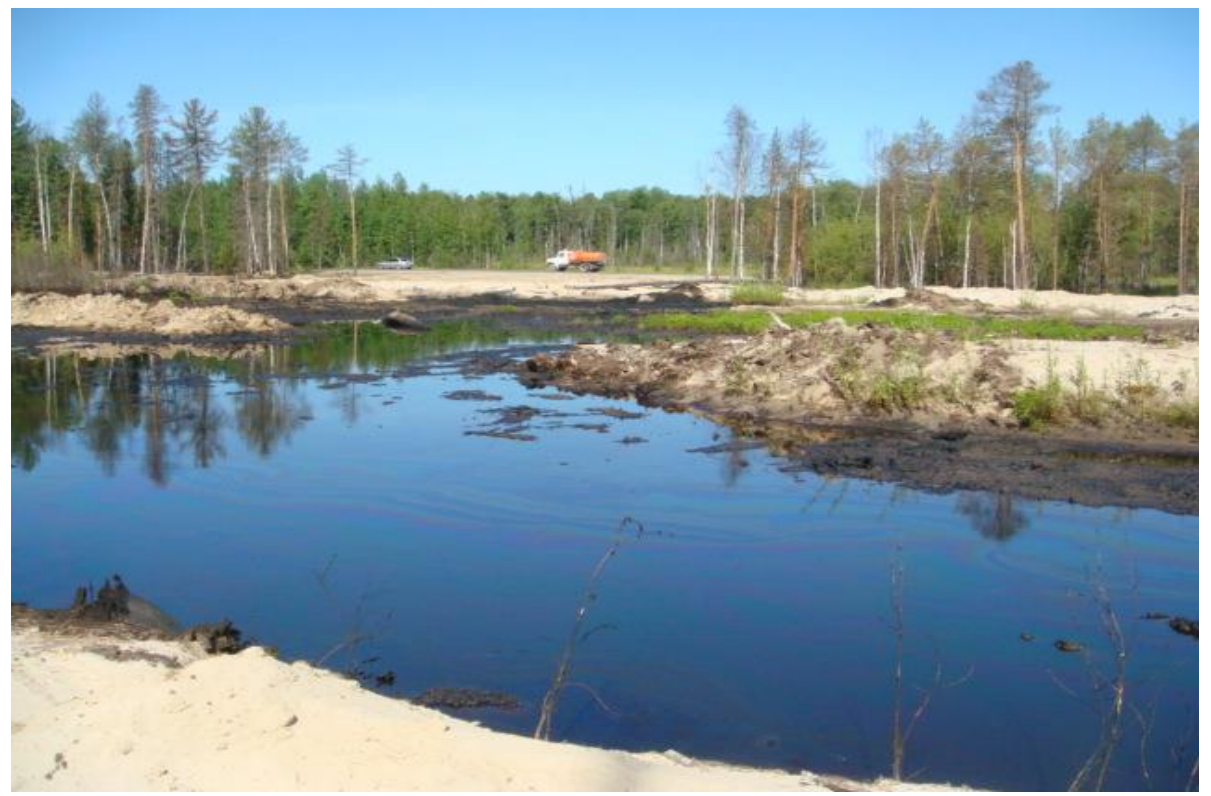

Fig. 4. Contamination of dry land (photo from the author's archive). 


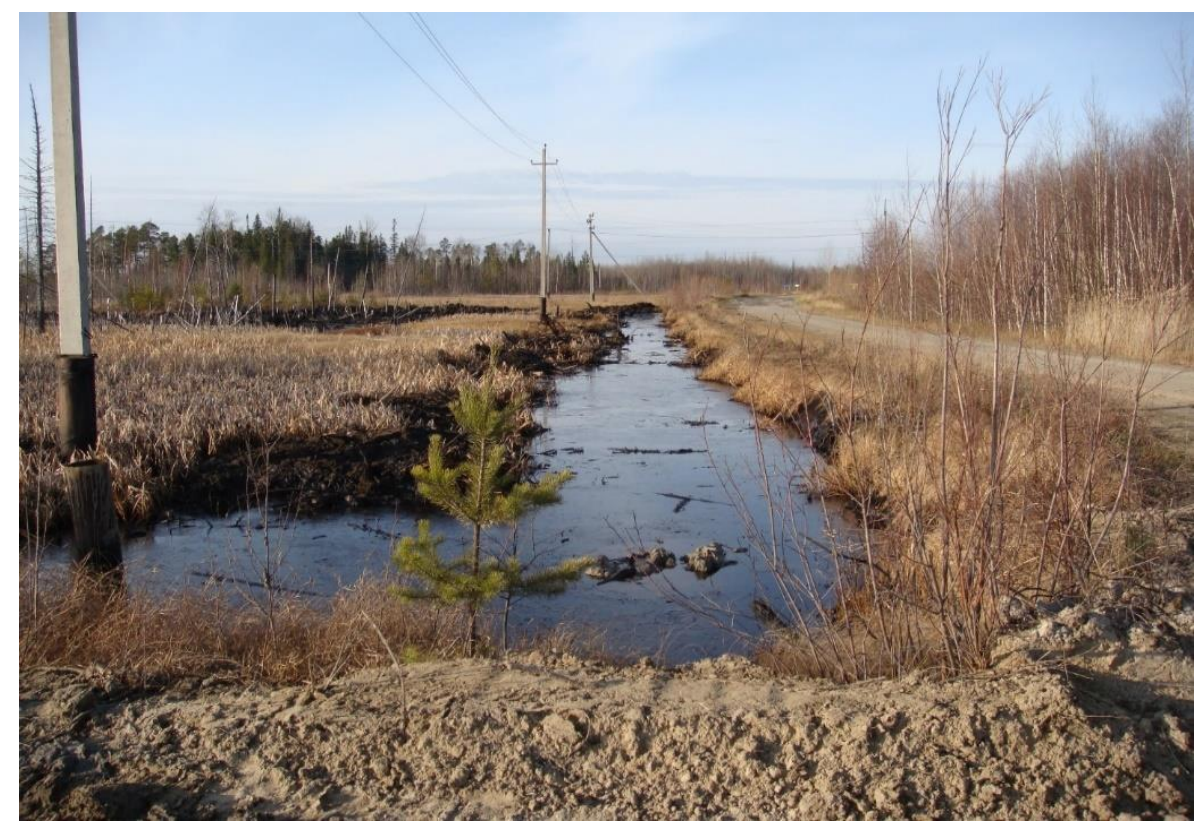

Fig. 5. Oil spill leading to pollution of a roadside ditch (photo from the author's archive).

The above examples clearly show that the approach to reclamation should be individual in each specific case.

\section{Results}

Reclamation works carried out according to the "standard" WPP [4] do not take into account the peculiarities of the contaminated site, which often leads to the need to adjust the types and volumes of work both at the technical and biological stages of reclamation. The scope of work that is carried out in the elimination of an emergency situation for the collection of oil, oily soils and water, as well as the delivery of soil for bunding the site is recorded only by estimates and are not considered in the WPP. With this approach, the natural environment remains under constant negative impact.

In fact, different contractors perform reclamation according to the same WPP at their own discretion: some contractors prefer to cover the remaining contaminated soils with soil, others prefer milling with the depth of milling being freely set. This approach leads to the fact that the remaining oil often comes to the surface after minor disturbance of the surface soil layer, as shown in figure 6.

Low efficiency is manifested in milling an oil-contaminated area or plowing it with a full rotation of the layer, since the use of such agrotechnical methods only contributes to the burial of the contaminant at a depth where it is impossible to fight it. In this case, the full meaning of reclamation is lost, which should be aimed at eliminating the consequences of pollution and not causing more damage to the ecosystem than that which has already been caused by pollution.

In the climatic conditions of Western Siberia, during the biological stage before sowing grasses, various bacterial preparations are widely used, which have proved themselves quite well as destructors of oil and oil products components in the elimination of pollution within water bodies. However, their use in relation to the massifs of oil-contaminated soils is ineffective in most cases. 


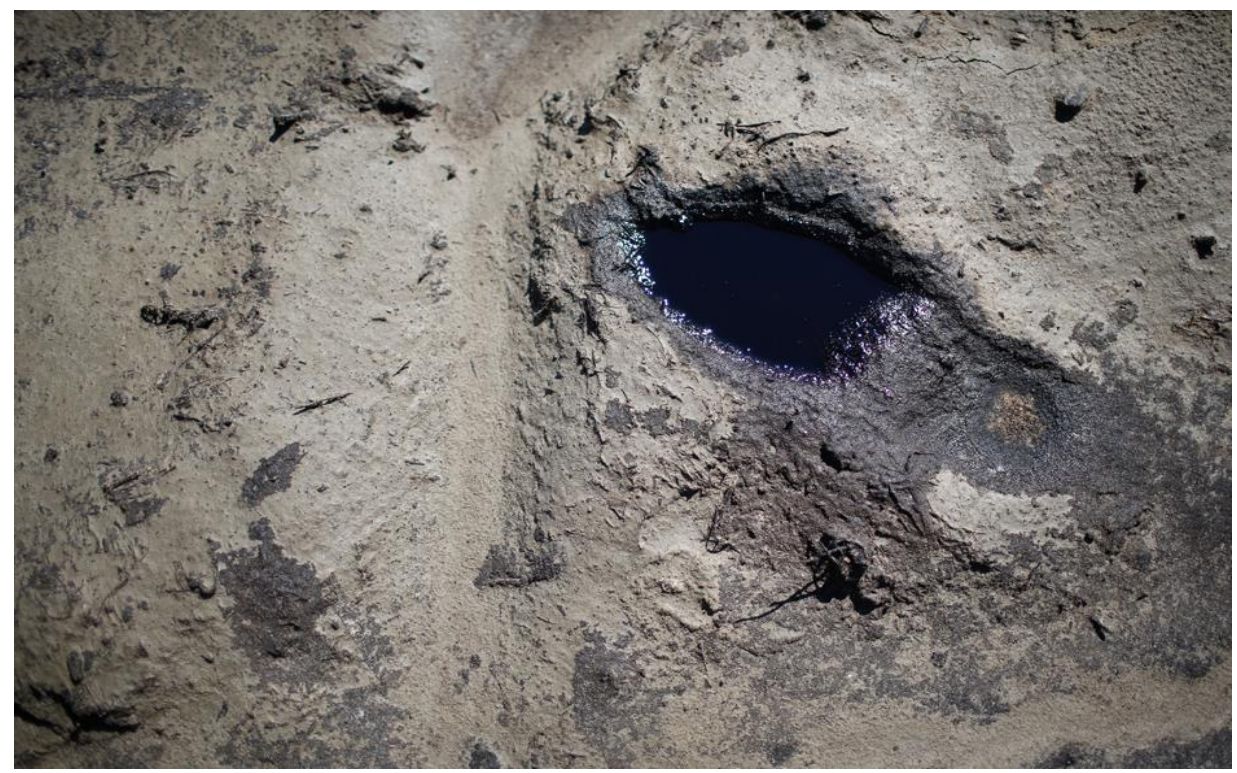

Fig. 6. Occurrence of oil on the surface of the reclaimed area.

The main reason for the low efficiency of the use of bacterial preparations lies in the fact that long-term positive temperatures are necessary for the active vital activity of the microorganisms that make up their composition. But the warm period of the year in the territories of West Siberian hydrocarbon deposits is rather short; moreover, permafrost soils are often present at a shallow depth from the earth's surface.

In common practice, reclamation means the restoration of the original fertility of previously disturbed lands. This is the ultimate goal of any reclamation work. The purpose of reclamation of oil-contaminated land is to reduce its content in soil and water to safe concentrations. The main danger is posed by carcinogenic and mutagenic substances contained in oil, but their low concentrations almost do not affect the productivity of the first generations of vegetation. In practice, the final results of reclamation are assessed just by the germination of herbage in the first, rarely the second year of completion of work. The growth of herbage cannot serve as a criterion for assessing the effectiveness of reclamation. It only indicates a decrease in the concentration of oil in the soil below the phytotoxicity limits for certain plant species and soil types. Figure 7 shows a block diagram of the organization of the reclamation work, depending on which site the pollution occurred. In practice, in the conditions of Western Siberia, one pollution site usually affects both dry land and bog, and then enters rivers and lakes. This circumstance emphasizes the need for an individual approach to the choice of reclamation technology, which is determined by the project. 


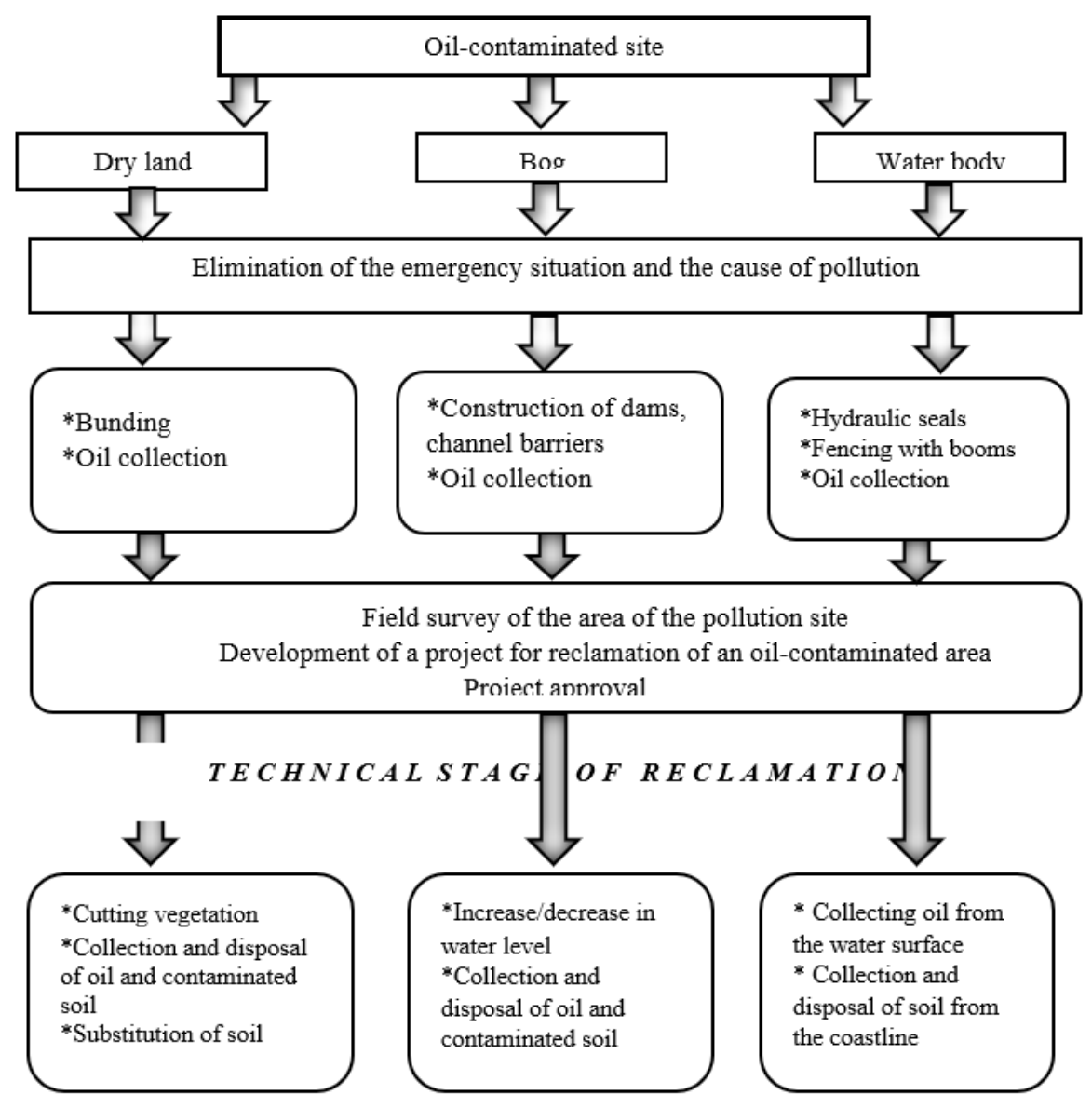

BIOLOGICAL STAGE OF RECLAMATION



Fig. 7. Block diagram of the organization of the reclamation of an oil-contaminated site on dry land, bog and water body.

The current standards show that in the event of oil pollution of lands, the rapid achievement of the true goal of reclamation is to ensure the biological safety of contaminated lands and the biomass developing on them. But, as practice shows, this is possible only with the complete removal of the contaminated soil from the spill site and replacing it with clean fertile soil. A feature of the oil fields in Western Siberia is that $85 \%$ of the land on which the fields are located is not directly used in agricultural circulation. Perhaps this circumstance explains the simplified approach to monitoring the results of reclamation. In this case, the real goal of reclamation work is only to reduce the content of 
oil and oil products in the soil to a certain limit [4], at which the development and reproduction of many species of green plants is possible with the oil content in the soil up to several percent (depending on the type of soil). There are oil-resistant plants, for example, cattail successfully grows on some old oil spills. Oil is a growth stimulant for it. Deeper studies show that the accumulation of mutagens and carcinogens in plants makes these plants dangerous for higher life forms.

For this reason, even after the restoration of the fertility of the reclaimed lands, they should not be used for growing food and fodder plants. On such lands, you cannot mow hay and graze livestock, you cannot pick mushrooms and berries. You should not fish in oily waters. The only criterion for removing these restrictions may be the results of special physicochemical and toxicological studies of the soil, plants growing on it and inhabitants of reclaimed oil-contaminated water bodies.

\section{Discussion}

Nowadays, oil refineries on the territory of oil fields are working on elimination of oil spills and reclamation of oil-contaminated land, but it is noted that the quality of land reclamation is far from the required goals [8]. The main reason for the low quality of reclamation works is the low quality of the projects being developed, as well as deliberate simplifications of the technology of reclamation works.

At the technical stage of reclamation, the main mistake during reclamation of oilcontaminated lands is backfilling of spilled oil with soil. This leads to the fact that spilled oil does not undergo microbiological oxidation, but becomes a source of permanent pollution of ground and groundwater for many years. Milling of an oil-contaminated area from the surface of which the spilled oil was poorly collected leads to the same effect.

At the biological stage of reclamation, a serious mistake is the use of bacterial preparations without high-quality agrotechnical land cultivation.

Introduced preparations of hydrocarbon-oxidizing bacteria with mineral fertilizers on the surface of the site subjected to technical reclamation clean its surface and promote selfovergrowing by grass. In this case, the impression is created that the biological stage of reclamation is effective. However, not decomposed oil remaining in the depth of the soil, due to hydrophobization, migrates to the surface, which leads to the death of vegetation. As a result, the site becomes partially uncultivated in one or two years, and the pollution of soil and surface waters by oil components will continue. As a result, the objectives of reclamation will be achieved only partially with a clear external wellbeing at the time of completion of the work.

Assessment of the effectiveness of reclamation works by the intensity of grass growth on them during the first year is a significant mistake.

\section{Conclusions}

In conclusion, it should be noted that there is a need for a deeper study of the issues of reclamation of oil-contaminated areas, taking into account all the features of both each oilcontaminated site separately and the entire region as a whole. It is unacceptable to use a typical project for reclamation of various oil-contaminated areas. The project should be developed only on the basis of a field survey of the pollution site and the collection of all initial data, while it is possible to divide the development of the project into two stages. At the first stage, measures are developed for carrying out the technical stage of reclamation, at the second stage - for the biological one. The implementation of this idea will significantly reduce the project development time, improve the state of affairs with the 
reclamation of oil-contaminated lands in the specific climatic and geographical and landscape conditions of oil fields in Western Siberia.

From an environmental point of view, it is unacceptable to violate the reclamation technology at all stages of its implementation and assess the effectiveness of reclamation by the germination of herbage and the content of oil products only in surface soil samples. It is necessary to search for the most effective and test new schemes for the reclamation of oilcontaminated territories. What works well in the middle zone is not acceptable in the conditions of Western Siberia.

\section{References}

1. GOST 17.5.1.02-85. Protection of Nature. Land. Classification of disturbed lands for reclamation (Gosstandart of the USSR, M., 1986)

2. GOST R 57447-2017 Best Available Techniques. Reclamation of lands and land plots contaminated with oil and oil products. Basic provisions (Standartinform, M., 2019)

3. Register of territories and water bodies of the Khanty-Mansi Okrug - Yugra contaminated with oil, oil products, bottom water, by enterprises (2020)

4. A.V. Saromotin, Study of the effectiveness of reclamation methods // Materials of the district meeting (Khanty-Mansiysk, 1997)

5. Typical project for the reclamation of oil-contaminated land at the fields of $R N$ Yuganskneftegaz LLC (Surgut, 2012)

6. Reclamation project of oil-contaminated forest lands in the area of activity of $R N$ YUGANSKNEFTEGAZ LLC (Mamontovsky, Maysky, Pravdinsky regions, Nefteyugansky district, Nefteyuganskoye forestry, Tyumen, 2015)

7. I.Yu. Grigorieva, Oil pollution of soils: engineering-geological and ecologicalgeological aspects (LAP LAMBERT Academic Publishing $\mathrm{GmbH} \&$ Co. KG, Germany, 2010)

8. I.Yu. Grigorieva, D.Yu. Baranov, A.M. Abyzova, Engineering survey 13, 48-57 (2015)

9. I.Yu. Grigorieva, A.N. Shestakova, Engineering Geology 1, 30-33 (2009)

10. L.P. Kapelkina, L.A. Malyshkina, Scientific journal “Oil Industry” (2015) ISSN:00282448 